\title{
Dawid Mikołajczak
}

ORCID: 0000-0002-7365-8714

Uniwersytet Wrocławski, Wydział Prawa, Administracji i Ekonomii

293252@uwr.edu.pl

\section{Idea neutralności pieniądza a wybrane nurty ekonomii}

Artykuł nadesłany: 6.01.2019; artykuł zaakceptowany: 28.02.2019

Kody klasyfikacji JEL: B22, B31, E51

Keywords: neutrality of money, Monetarism, Austrian School, RBC, Keynesianism

\begin{abstract}
Money neutrality and selected currents in economics

The history of the idea of neutrality of money begins with David Hume. There are at least five types of money neutrality. They could be grouped into neutrality relating to the moment (static neutrality and institutional neutrality) and neutrality relating to the period (dynamic neutrality, superneutrality, monetary neutrality). In mainstream economics, views on neutrality have changed over the years. Monetarism has differentiated views on the neutrality of money. The Austrian school remains sceptical about this simplification of the monetary economy. The theory of the real business cycle accepts any kind of neutrality in the period, and neutrality at the moment is not an important issue for it. Keynesianism focuses on neutrality in the short term and is sceptical about it.
\end{abstract}

\section{Wstęp}

Neutralność pieniądza jest jednym z centralnych pojęć teorii pieniądza. Stosunek do niej zmieniał się na przestrzeni lat. Obecnie powszechnie zakłada się, że cechuje ona określone zjawiska monetarne w długim okresie, podczas gdy okresy krótki i średni są czasem przejściowych zmian realnych. Jednak nie wszyscy podzielają ten pogląd. Jeden z najpopularniejszych podręczników zauważa, że „teoria ta jest jedynie uogólnieniem" (Samuelson i Nordhaus, 2012, 497). Anglojęzyczna Wikipedia przytacza następującą definicję: „Idea, według której zmiana podaży pieniądza wpływa tylko na nominalne zmienne w gospodarce, takie jak ceny, wynagrodzenia, kursy walut, a nie wpływa na zmiany realne, takie jak zatrudnienie, 
realne PKB i konsumpcję". Na bardziej zaawansowanej merytorycznie stronie Investopedii znajduje się podobne wyjaśnienie: „Teoria ekonomiczna stwierdzająca, że zmiany w podaży pieniądza wpływają tylko na zmienne nominalne, a nie na realne". Jest to najczęstsze pojmowanie tego terminu. Pojawia się w nim ważne rozróżnienie. Aby je wyjaśnić, cofnę się do jego historycznego początku.

Uznaje się, że początki idei neutralności pieniądza są zawarte w podziale na wartości nominalne i realne, wprowadzonym przez Davida Hume'a (można więc powiedzieć, że omawiany koncept jest starszy niż ekonomia jako nauka, jeśli jej początek datujemy na wydanie Bogactwa narodów w 1776 roku). Rozdział ten wraz z brakiem wzajemnych oddziaływań opisywanych przez niego sfer nazywa się klasyczną dychotomią (Sieroń, 2017, 14). Został on rozpowszechniony, a następnie utrzymany przez ekonomię klasyczną i stanowił ważny jej element. Jednak wspomniany ekonomista i filozof nie uważał, że pieniądz jest zupełnie bez znaczenia. Jego poglądy wyrażone w eseju „O pieniądzu” z Political Discourses z 1752 roku są bardziej skomplikowane i bliższe poglądom współczesnym. Chcę zwrócić uwagę na kilka przekonań zawartych we wspomnianym tekście:

- o braku znaczenia ilości pieniądza w obiegu (które będę dalej nazywał „neutralnością statyczną”): w tekście wyjaśniane na przykładzie królestwa w odseparowaniu od innych. Ceny są ujęte jako „zawsze proporcjonalne do ilości pieniądza" (Hume [1742], 2014, 9);

- o braku znaczenia zmiany ilości pieniądza (które będę dalej nazywał „neutralnością dynamiczną"), w długim okresie: jest to wniosek, o którym autor twierdzi, że wypływa logicznie z poprzedniego;

- o istnieniu okresu nieneutralności pieniądza: autor dostrzega jego istnienie i nazywa okresem przejściowym. Podczas jego trwania ceny dostosowują się do nowych warunków w kolejności ustalonej przez drogę, jaką nowy pieniądz dostaje się do gospodarki. Opisywał więc efekt Cantillona, lecz niezależnie od osoby, na której cześć został on tak nazwany - świadczy o tym fakt, że nie odnosi się do niego;

- o pozytywnym wpływie inflacji i negatywnym deflacji w okresie przejściowym: „Gdy ilość pieniądza maleje, państwo jest słabsze i bardziej nieszczęśliwe niż to, które w danej chwili posiada tyle samo pieniędzy, lecz ilość ta wzrasta" (Hume [1742], 2014, 15). Jest to element ekonomii normatywnej. Cytowane zdanie dotyczy konkretnie wpływu okresu przejściowego na przemysł;

- o negatywnym skutku wzrostu cen dla handlu zagranicznego: „Ogólnie rzecz biorąc, możemy zauważyć, że wysokie ceny wszystkich dóbr spowodowane nadmiarem pieniądza są wadą, która w każdym państwie towarzyszy rozwiniętemu handlowi i krępuje go, gdyż państwa biedniejsze mogą z nim konkurować na zagranicznych rynkach" (Hume [1742], 2014, 11).

Poglądy Davida Hume'a miały bezpośredni wpływ na Adama Smitha — pokazuje to ich wagę dla historii myśli ekonomicznej. Przed nimi ekonomią zajmowali się między innymi merkantyliści utożsamiający ilość kruszcu (używanego 
wtedy jako środka wymiany) z dobrobytem. Innym ważnym dla teorii pieniądza ekonomistą był Richard Cantillon, który opisał efekt pierwszej rundy jako jedną z przyczyn nieneutralności pieniądza. Od czasów pionierów teorii pieniądza do dziś stworzono wiele pojęć i teorii oraz wykonano wiele badań ekonometrycznych wnoszących nową jakość do zasady neutralności pieniądza. Jedną z nich jest wyróżnienie jej odmian, które dotyczą odrębnych klas pojęć i zjawisk. Niniejsza ich klasyfikacja została zaczerpnięta z książki Efekt Cantillona - czyli dlaczego pieniadza ma znaczenie? A. Sieronia, a następnie rozwinięta w wybranych punktach.

\section{Neutralność pieniądza}

Przy wyjaśnianiu pojęcia będącego tematem tej pracy będę posługiwał się oznaczeniami zawartymi w równaniu wymiany. Ma ono następującą postać:

$$
\mathrm{M} * \mathrm{~V}=\mathrm{P} * \mathrm{Y}
$$

Gdzie:

$\mathrm{M}$ - podaż pieniądza

V - szybkość obiegu pieniądza

$\mathrm{P}$ - przeciętna cena transakcji

$\mathrm{Y}$ - realne PKB

W najpopularniejszym ujęciu neutralność pieniądza oznacza brak zależności między zmianą M a Y albo M a Y i V, w najszerszym zaś można ją rozumieć jako brak wpływu zjawisk monetarnych na zmienne realne (Sieroń, 2017, 13). Jak widzimy, definicje te się różnią. Pierwszą różnicą jest stałość szybkości obiegu pieniądza, która zostanie omówiona w podrozdziale 1.2. Druga różnica zawiera się w słowie „zmiana”. Owo słowo oznacza założenie kategorii czasu, a ona analizę dynamiczną.

Gdy ekonomiści mówią „czas”, mogą mieć na myśli kilka pojęć. Neutralność można rozpatrywać z punktu widzenia momentu i okresu.

Próby sprowadzenia do siebie tych dwóch pojęć często generują paradoksy. Potraktuję ową dychotomię jako podstawową dla systematyki rodzajów neutralności pieniądza.

\subsection{Neutralność w momencie}

Z powodu niemożliwości analizy dynamicznej pozostaje mi analiza porównawcza. Kryterium analizy będzie wielkość M. Istnieją dwa typy gospodarek: pieniężna i niepieniężna, a co za tym idzie, trzy możliwe porównania: pieniężna-pieniężna, pieniężna-niepieniężna, niepieniężna-niepieniężna. W pracy rozpatruję przypadki pierwszy i drugi, gdyż w ostatnim pieniądz nie występuje. 


\subsubsection{Neutralność statyczna}

Neutralność statyczna oznacza, że wielkość podaży pieniądza w gospodarce nie ma związku ze sposobem jej działania. O braku neutralności statycznej można mówić, gdy powodem jakiegokolwiek zjawiska realnego jest sam fakt posiadania większej ilości pieniądza.

Wielu ekonomistów - nawet sceptycznie nastawionych do głównej idei tego tekstu — zakłada, że pieniądz spełnia ten warunek. Jest to spowodowane postawieniem nieprzenikliwej, sztywnej granicy między wartością nominalną a realną oraz traktowaniem pieniądza wyłącznie jako domeny tej pierwszej. Jest to jednak pewne uproszczenie. Siła nabywcza ma swój nośnik, którym jest fizyczna postać pieniądza potencjalnie taktowana jak towar — jest on częścią sfery realnej.

Posłużę się eksperymentem myślowym: gdy państwo A ma dwa razy więcej pieniądza niż państwo B, waluta A jest dwa razy mniej warta niż w państwie B i tylko tyle implikuje neutralność statyczna pieniądza. Następuje jednak jeszcze jedna różnica, którą jest — zakładając używanie tych samych nominałów — dwukrotnie większa objętościowo forma nośnika siły nabywczej (o ile w obu państwach mają taki sam rozmiar). W normalnych sytuacjach ekonomicznych nie wpływa to na resztę gospodarki. Jednak w przypadku gdy czynnik ten jest bardzo intensywny, decyduje on o powstaniu nowych kosztów transakcyjnych.

Sytuacją gospodarczą, która generuje takie zjawisko, jest między innymi hiperinflacja. Współczesnym przykładem państwa dotkniętego takim problemem jest Wenezuela (tradingeconomics.com, 2018), gdzie przenoszenie dużej ilości pieniędzy stało się odczuwalne dla obywateli — wraz z wieloma innymi czynnikami spowodowało wzrost popularności innych środków wymiany.

Wątkiem wartym wspomnienia jest różnica między pieniądzem (rzeczą) a jednostką pieniężną (nazwą). Podczas wyjaśniania opisywanej koncepcji często sugeruje się następujący eksperyment myślowy: rząd postanowił zatwierdzić, że to, co wcześniej było półdolarem, obecnie jest dolarem — czy cokolwiek w sferze realnej się zmieniło? Odpowiedź brzmi: nie — jedyna różnica polega na dwukrotnym podwyższeniu cen. $\mathrm{W}$ gruncie rzeczy nie jest to jednak zmiana $\mathrm{M}$, tylko zmiana nazwy $\mathrm{M}$, ponieważ fizyczne pieniądze zostały dokładnie w takiej samej ilości, co wcześniej. Rzeczywistość się nie zmieniła. Zmienił się język, którym się posługujemy.

W normalnych sytuacjach gospodarczych neutralność statyczna pieniądza dokładnie opisuje rzeczywistość ekonomiczną. W sytuacji gdy środek wymiany traci własność poręczności, w znacznym stopniu doprowadza to do zmian realnych, a omawiana zasada traci swoją użyteczność dla teorii ekonomii. Jest to jednak sytuacja rzadka i prawdopodobnie niemająca wielkiego wpływu. Sprawia to, że uważa się ją za nieistotną i zakłada naturalność statyczną. 


\subsubsection{Neutralność instytucjonalna}

Drugim przykładem neutralności w momencie jest neutralność instytucjonalna. Można ją zdefiniować jako brak wpływu istnienia pieniądza na funkcjonowanie gospodarki. O ile w poprzedniej części porównywaliśmy dwa państwa o różnych $\mathrm{M}$, tutaj porównamy państwa, z których tylko jedno używa pieniądza.

Neutralność instytucjonalna opiera się na tej samej zasadzie co naturalność statyczna, czyli na klasycznej dychotomii — postulacie szkoły klasycznej, oznaczającym możliwość analizowania osobno (bez uwzględniania ich wpływów na siebie) wartości nominalnych i realnych.

Można pomyśleć, że różnica $\mathrm{w}$ działaniu gospodarki barterowej i pieniężnej jest oczywista. Pieniądz rozdziela kupno od sprzedaży, co ułatwia wymianę - aby zaszła transakcja, potencjalny nabywca jakiejś rzeczy nie musi szukać osoby, która będzie ją miała i jednocześnie będzie chciała coś, co on ma. Jest to niewłaściwe spojrzenie. Myśląc o neutralności instytucjonalnej, należy wyobrazić sobie gospodarkę towarową, w której występują dokładnie takie same transakcje jak w pieniężnej, a następnie je porównać. Wystąpienie takiej sytuacji jest tak nieprawdopodobne, że brzmi absurdalnie, ale to jedyny sposób, w jaki możemy stwierdzić, czy sam fakt istnienia pieniądza tworzy różnicę.

Wielu ekonomistów uważało, że gospodarkę można analizować jako wymiany towarów za towary, a następnie dodać wartości nominalne, tak jakby nie miały one wpływu na całą resztę.

O wspomnianej analizie porównawczej można powiedzieć jeszcze kilka rzeczy. Klasę możliwych gospodarek pieniężnych można zawęzić bardziej niż do takich z niezerową podażą pieniądza. Podaż danego środka wymiany musi być na tyle duża, żeby wymiana nabrała cech podzielności, akceptowalności i rozpoznawalności, by stać się pieniądzem.

Można by uznać, że pieniądz jest neutralny instytucjonalnie, gdy gospodarka, w której M jest równe zeru, jest identyczna z wszystkimi gospodarkami pieniężnymi (nie ma powodu, by porównywać tylko z jedną). Do tego wszystkie gospodarki pieniężne muszą być identyczne. Implikuje to neutralność statyczną. Jednak to nietrafne ujęcie. Autorzy często przyjmują, że nawet jeśli w analizie porównawczej zauważają różnicę, to jest ona nieistotna i może zostać pominięta. Daje to możliwość przyjęcia neutralności statycznej bez przyjmowania neutralności instytucjonalnej.

\subsection{Neutralność w okresie}

Teoria neutralności w okresie jest — ze względu na istotność jej następstw dużo bardziej rozbudowana i jednocześnie trudniejsza w analizie. Pokazuje to powszechne skupienie się nad nią w teorii ekonomii. 
Analogicznie do neutralności w momencie w myśli ekonomicznej wyodrębniły się dwie sytuacje: porównująca pewne dwie niezerowe wielkości (pewną wielkość $\mathrm{M} \mathrm{z}$ inną wielkością $\mathrm{M}$ ) oraz porównująca wielkość niezerową $\mathrm{z}$ wielkością zerową (pewną wielkość $\mathrm{M}$ z brakiem $\mathrm{M}$ ). W tym podrozdziale rolę podaży pieniądza przejmie zmiana tempa inflacji.

Oprócz tego można wymienić przypadek szczególny, który uwzględnia szybkość obiegu pieniądza. W części 1.1. nie może być podobnej sytuacji, ponieważ $\mathrm{V}$ w definicji zawiera kategorię czasu.

\subsubsection{Neutralność dynamiczna}

Neutralność dynamiczna jest najważniejsza z punktu widzenia myśli ekonomicznej — na niej ekonomiści koncentrują najwięcej uwagi. Oznacza ona, że jednostajna zmiana podaży pieniądza nie wpływa na czynniki realne. Słowo, ,jednostajna" w definicji jest ważne, lecz często pomijane przez autorów podręczników lub książek o tej tematyce. Jego waga polega na odróżnieniu jej od superneutralności — założeniu, że zmieniające się tempo zmiany M nie wpływa na sferę realną. Gdy ze zbioru sytuacji oznaczonych słowem „zmiana M” wyłączymy zbiór sytuacji oznaczonych przez ,zmiana tempa zmiany M”, zostanie tylko „zmiana M o niezmiennym tempie".

Najprostszym przykładem jest jednokrotne zwiększenie sald gotówkowych u kilku uczestników gospodarki działającej jednostajnie (czyli takiej, w której czynności powtarzają się w identyczny sposób w nieskończoność [Rothbard, 2007a, 10]). Po takiej jednokrotnej podwyżce nastąpią zmiany realne spowodowane między innymi sztywnościami cenowymi, efektem Cantillona czy niepełną informacją, a następnie gospodarka powróci do równowagi. Po dostosowaniu się rynku działanie inflacji jest zakończone. Okres nieneutralności pieniądza jest nazywany okresem dostosowawczym.

$\mathrm{Z}$ neutralności dynamicznej wynika neutralność statyczna. Jeśli zmiana $\mathrm{M}$ nie wpływa na $\mathrm{Y}$, to sfera realna $\mathrm{z}$ początku okresu dostosowawczego jest taka sama, jak sfera realna po jego zakończeniu. Może istnieć dowolnie wiele sytuacji gospodarczych o takiej samej sferze realnej, które różnią się pod względem podaży pieniądza. Często (jak choćby u Hume’a) neutralność statyczna jest podawana jako wstęp do zrozumienia dynamicznej.

\subsubsection{Superneutralność}

Neutralność dynamiczna dotyczy sytuacji, w których wahania inflacji nie występują. Superneutralność zakłada, że zmiana tempa inflacji nie powoduje zmian realnych. Jest więc komplementarna wobec neutralności dynamicznej. To założenie ważne dla polityki monetarnej, gdyż cele inflacyjne nie są w każdym okresie takie 
same. Gdy inflacja jest liczona względnie długimi okresami, może wyglądać na stabilną, ale im bardziej skraca się okres, tym więcej wahań można zauważyć. Posłużymy się przykładem. Załóżmy, że inflacja jest liczona rocznie. W roku A wynosi 7,1\% i w B też 7,1\%. Inflacja w ciągu dwóch lat jest stała, więc na pierwszy rzut oka wygląda na to, że pieniądz musi być tylko neutralny do braku zmian realnych $\mathrm{w}$ gospodarce. Teraz zakładam jej sześciomiesięczne liczenie. Tempo inflacji w kolejnych półroczach wynosi: A1 - 5\%, A2 - 2\%, B1 - 2\%, B2$5 \%$. Te dane wprowadzają nowe informacje. Nawet w modelu, w którym zakłada się neutralność dynamiczną pieniądza, zachodzą zmiany realne, gdyż inflacja zmienia swoje tempo. Aby model nie przewidywał zmian realnych, potrzebne jest założenie o superneutralności. Pojawia się pytanie: jeśli chcemy spekulować na temat zachowania prawdziwej gospodarki z uproszczeniem dotyczącym pieniądza, to powinniśmy założyć superneutralność, czy może tylko zwykłą neutralność? Kiedy dwie inflacje są od siebie na tyle oddalone w czasie, by były dwoma oddzielnymi, a nie jedną inflacją zmieniającą swoje tempo?

Zakładam neutralność dynamiczną pieniądza w dalszym rozumowaniu. Jeśli dwie podwyżki ogólnego poziomu cen występują w wystarczająco dużym odstępstwie czasowym, to są traktowane jako dwie różne inflacje, a nie jedna o zmiennym tempie. Można stąd wywnioskować, że im bliżej siebie są, tym bardziej wywołują zmiany realne. Jednocześnie jeśli dwie zmiany poziomu cen występują prawie w tym samym czasie, to wywołają skutki jednej, gdyż uczestnicy rynku przeważnie nie są w stanie dostosować swojego działania z dnia na dzień. Oznacza to, że inflacje muszą być również dostatecznie daleko od siebie.

\subsubsection{Neutralność monetarna}

Neutralność monetarna jest szczególnym przypadkiem neutralności pieniądza. Oznacza ona, że pieniądz jest neutralny i w stosunku sfery realnej, i do ogólnego poziomu cen. Czyli zmiany dotyczą tylko popytowej strony równania wymiany. Można ją więc zdefiniować jako brak wpływu zmiany M na P i Y.

Jest ona o tyle szczególna, gdyż nie skupia się tylko na ilości pieniędzy w obrocie gospodarczym, lecz na sumie wartości nominalnych wszystkich transakcji w danym czasie.

Podkreślenie wagi prędkości obiegu w analizie efektów realnych zmian podaży pieniądza może stanowić krok w stronę rozwiązania pewnych kwestii makroekonomicznych. Przykładem jest fakt, że w 2009 roku mimo luzowania ilościowego przeprowadzonego przez Fed nie nastąpił proporcjonalny wzrost inflacji czy PKB.

Jak można zauważyć, jednym z przypadków neutralności monetarnej jest pułapka płynności, którą niektórzy ekonomiści tłumaczą wspomniany brak skutków działań Fedu. 


\subsection{Podsumowanie systematyki}

Całościowo klasyfikację neutralności pieniądza pokazuje poniższa tabela:

Tabela 1. Klasyfikacja neutralności pieniądza

\begin{tabular}{l|l}
\hline \multicolumn{1}{c|}{ Neutralność } & \multicolumn{1}{c}{ Definicja } \\
\hline W momencie & M nie wpływa na sferę realną w momencie \\
\hline Statyczna & Wielkość M nie wpływa na sferę realną \\
\hline Instytucjonalna & Istnienie M nie wpływa na sferę realną \\
\hline W okresie & Zmiana M nie wpływa na sferę realną \\
\hline Dynamiczna & Jednostajna zmiana M nie wpływa na sferę realną \\
\hline Superneutralność & Zmiana tempa zmiany M nie wpływa na sferę realną \\
\hline Monetarna & Zmiana M nie wpływa na sferę realną i poziom cen \\
\hline
\end{tabular}

Źródło: opracowanie własne.

Istotnym elementem jest to, że zmiany monetarne są przyczyną, a zmiany realne są skutkiem. W wypadku odwrócenia tego związku pieniądz również jest neutralny (to sfera realna nie jest neutralna).

\section{Neutralność pieniądza a monetaryzm}

Monetaryzm od lat siedemdziesiątych jest jedną z najważniejszych szkół ekonomii. Jej podstawy były tworzone przez Miltona Friedmana w latach pięćdziesiątych w serii publikacji. Najistotniejszą dla kwestii neutralności pieniądza jest The Quantity Theory of Money: A Restatement z 1956 roku. Myśl zawarta w artykułach była opozycyjna wobec dominującego wówczas na wielu płaszczyznach keynesizmu, między innymi teorii bezrobocia, krzywej Philipsa, podejściu do inflacyjnej polityki monetarnej, teorii pieniądza.

Dla monetaryzmu, z powodu swojego skupienia na polityce pieniężnej, kwestia neutralności jest kluczowa. Stosunek Friedmana do niej zaważył na obecnym postrzeganiu owej idei w głównym nurcie, częściowo wypierając podejście keynesowskie.

Znanym eksperymentem myślowym opisywanym przez Friedmana jest helikopter zrzucający pieniądze w równomierny sposób na danym terenie. Każdy członek społeczeństwa po takim nalocie zebrałby nowe pieniądze i tym samym podwoiłby swoje saldo gotówkowe. Po pewnym czasie ludzie stanęliby przed wyborem: zachować zwiększone środki pieniężne (co jest równoznaczne ze zmniejszeniem V) bądź je wydać. O pierwszej opcji autor napisał, że ,ludzie nie postępują w taki sposób. Nie pojawiły się przecież żadne czynniki nakłaniające ludność do zwiększenia posiadanych zasobów gotówkowych" (Friedman, 1994, 34). 
Oznacza to wykluczenie neutralności monetarnej jako cechy pieniądza w danej sytuacji. W dalszej części Friedman opisuje alternatywne wyjście: zachowanie V na stałym poziomie. Naturalnie powoduje to zwiększenie P lub Y. Jednak zwiększenie podaży pieniądza nie prowadzi do zmian preferencji konsumentów i producentów, granicy możliwości produkcyjnych, uzbrojenia technicznego pracy i innych zmiennych realnych gospodarki.

To drugie wyjście jest jednak obecne tylko w analizie długiego okresu. Krótki okres jest $\mathrm{w}$ teorii pieniądza utożsamiany $\mathrm{z}$ okresem przejścia (Friedman, 1994, 36) - lub inaczej okresem dostosowawczym — w którym do nieneutralności pieniądza przyczyniają się niepełna informacja, sztywności cenowe, efekt Cantillona i wiele innych zjawisk. Długość jego trwania zależy od charakteru gospodarki. Przykładowym wymienianym w literaturze przedziałem jest okres od trzech do dziesięciu lat (Friedman, 1994, 54). O tym, jak dokładnie przebiegają wspomniane zjawiska cechujące okres dostosowawczy, decyduje wiele czynników społeczno-ekonomicznych. Ogólnie można uznać, że istnieje neutralność dynamiczna pieniądza w długim okresie.

W opisanym rozumowaniu pojawia się ważny warunek — wszyscy muszą być przekonani, że nie będzie więcej zrzutów pieniędzy z helikoptera.

Opis sytuacji, w której zrzuty pieniądza mają charakter ciągły, jest inny. Z pewną ilością powtórzeń powstaną oczekiwania inflacyjne. Racjonalnie działająca jednostka w takiej sytuacji zacznie zmniejszać krańcową skłonność do oszczędzania na rzecz krańcowej skłonności do konsumpcji w celu maksymalizacji użyteczności.

Friedman twierdzi, że w takim wypadku można powiedzieć więcej o okresie przejściowym: tempo inflacji przekroczy swój długookresowy poziom i pojawi się sytuacja typowa dla cyklu koniunkturalnego (Friedman, 1994, 40).

Autor wskazuje na błędne oczekiwania jako źródło „,przestrzelonego” tempa wzrostu cen i dochodów (Friedman, 1994, 40). Wskazuje też na fakt, że zmiana tempa inflacji powoduje niepewność, co zniechęca ludzi do przetrzymywania aktywów w formie gotówkowej (Friedman, 1994, 32).

Pod koniec rozumowania pojawia się konkluzja:

Kiedy jednak cała społeczność przejdzie procesy dostosowawcze do nowej sytuacji, może okazać się, że każdy człowiek stał się mniej zamożny w jej wyniku, gdyż:

— po pierwsze, przeciętnie każda osoba znajduje się w posiadaniu rezerw pieniężnych równych dochodom osiąganym w czasie 4 i 1/3 tygodnia, a nie — jak to miało miejsce wcześniej 5,2-tygodniowym przychodom; tak więc każdy stał się posiadaczem mniejszej rezerwy realnych zasobów pieniądza;

— po drugie, w wyniku sekwencji zdarzeń każdy członek społeczności uzyska mniejsze dochody realne, gdyż dokona zmniejszenia zasobów stanu swych zasobów wytwórczych na rzecz zwiększenia zasobów pieniądza, co z kolei zostało wymuszone sytuacją — relatywnym wzrostem cen dóbr i usług konsumpcyjnych w stosunku do cen czynników produkcji. (Friedman, 1994, 40)

Uznanie istnienia zmian realnych po zakończeniu takiego okresu dostosowawczego to zanegowanie założenia o superneutralności. 
Przechodząc do neutralności w momencie, warto zauważyć, że wyjaśnianie neutralności dynamicznej często jest poprzedzane przez wyjaśnienie neutralności statycznej. Friedman czyni podobnie, co oznacza, że monetaryzm ją zakłada. W podawanych przez siebie przykładach często zamienia jednostki pieniężne na realne salda gotówkowe lub czas potrzebny na uzyskanie dochodu o danej wielkości, argumentując, że te pozostają bez zmian w przypadku jednostajnej inflacji.

Kwestia neutralności instytucjonalnej nie jest tak często bezpośrednio poruszana przez monetarystów. Jednak zmienne realne nie są przez nich analizowane $\mathrm{w}$ odseparowaniu od zmiennych nominalnych, co wiąże się z odrzuceniem tego założenia.

Na podstawie wywodów Friedmana wnioskuję, że układ poglądów na neutralność pieniądza jest następujący:

Tabela 2. Neutralność pieniądza a monetaryzm

\begin{tabular}{|c|c|c|}
\hline Neutralność & Stosunek & Uzasadnienie \\
\hline W momencie & Niejednorodny & \\
\hline Statyczna & Pozytywny & $\begin{array}{l}\text { Utrzymywanie realnych sald gotówkowych na } \\
\text { tym samym poziomie niezależnie od ilości pie- } \\
\text { niądza w obiegu }\end{array}$ \\
\hline Instytucjonalna & Negatywny & $\begin{array}{l}\text { Zwracanie uwagi na czynniki monetarne pod- } \\
\text { czas analiz realnych }\end{array}$ \\
\hline W okresie & Niejednorodny & \\
\hline Dynamiczna & $\begin{array}{l}\text { Pozytywny w dhugim } \\
\text { okresie }\end{array}$ & $\begin{array}{l}\text { Powracanie zmiennych realnych do stanu równo- } \\
\text { wagi, istnienie okresu przejściowego }\end{array}$ \\
\hline Superneutralność & Negatywny & $\begin{array}{l}\text { Mniejsze utrzymywane realne salda gotówko- } \\
\text { we i mniejsze dochody realne nawet po okresie } \\
\text { przejściowym }\end{array}$ \\
\hline Monetarna & Negatywny & Ludzie utrzymują stałe realne salda gotówkowe \\
\hline
\end{tabular}

Źródło: opracowanie własne.

\section{Neutralność pieniądza a szkoła austriacka}

Szkoła austriacka (ASE) wyróżnia się na tle innych dążeniem do unikania uproszczeń i ostrożnością w stosunku do założeń. Ma to swoje następstwa w austriackiej teorii pieniądza. Jest ona alternatywą wobec popularniejszej ilościowej teorii pieniądza wykorzystywanej w głównym nurcie. Dwoma ważnymi dla tej pracy punktami niezgodności między tymi dwiema teoriami są: rozdział pieniędzy od towarów, oraz skupienie się na analizie danych zagregowanych. 
Pierwszy problem ma źródło w definicji pieniądza. Spojrzenie na środki wymiany jako na towary ma źródło już u twórcy ASE [Menger, 2011, 1]. W głównym nurcie ekonomii pieniądz postrzegany jest jako domena popytowej części gospodarki (MV), a towary jako podażowa (PY). Ekonomiści austriaccy nie wprowadzają takiego sztywnego rozróżnienia, czego przykładem jest, że w jednej z najbardziej znanych książek całościowo wykładających teorię ekonomii Rothbard jako alternatywę dla analizy podaży i popytu opisuje analizę całkowitego popytu na zasób, w której nie występuje krzywa podaży (Rothbard, 2007b, 268). Ten sam sposób myślenia jest również podkreślany w teorii pieniądza.

Drugi problem jest częścią ogólniejszej dyskusji — relacji między mikroekonomią i makroekonomią. Większość ekonomistów szkoły austriackiej nie przyjmuje tego podziału i skupia się na analizie wielkości niezagregowanych (choć można znaleźć ważne dla ASE książki pisane z zachowaniem tego podziału, jak Logika ekonomii Skousena $(2015,369))$. W teorii pieniądza implikuje to mniejszą wagę pojęcia ogólnego poziomu cen, a większą dotyczącą ich struktury. Istotnym zjawiskiem jest efekt Cantillona (inaczej zwany efektem pierwszej rundy) — fakt, że podaż M po gospodarce nie rozchodzi się w sposób równomierny, co wpływa na względne poziomy cen. Szczególny przypadek, w którym pieniądz dostaje się do rynku przez sektor kredytowy, oraz jego następstwa stanowią o austriackiej teorii cyklu koniunkturalnego, za którą w 1974 roku Hayek otrzymał Nagrodę Banku Szwecji im. Alfreda Nobla. Pokazuje to, jakie znaczenie ekonomiści austriaccy przypisują cenom relatywnym.

Poglądy te są w oczywisty sposób nie do pogodzenia z neutralnością w okresie. Założenie jej wykluczałoby najważniejsze dla tej szkoły obszary badań. Wspomniany efekt jest tylko jednym z wielu argumentów ASE. Przykładowymi są:

— niepełna informacja - jest to pojęcie o randze metodologicznej, z której szkoła austriacka nie może zrezygnować, gdyż wtedy byłaby już innym nurtem ekonomicznym;

— brak założenia o racjonalnych oczekiwaniach — podobnie jak poprzedni jest częścią inherentną opisywanej szkoły;

— koszty menu i lepkość cen — zjawiska związane ze zmianą cen; o ile pierwsze samo w sobie może zostać uznane za nieistotne, to wraz z drugim ma wagę przy kalkulacji ekonomicznej przedsiębiorców, dotyczącej zakupu dóbr kapitałowych.

Neutralność w momencie również rozpatruje się krytycznie. Jak wspomniałem, pieniądz to towar. Różnica między wymianą pośrednią a wymianą bezpośrednią jest ważna. Rothbard pisał:

Błąd popełniają niektórzy autorzy, pragnący wyjaśnić doktryny nowoczesnej ekonomii, analizując wymianę bezpośrednią, a następnie umieszczając pieniądz gdzieś pod koniec analizy i uważając, że zadanie zostało wykonane. Wręcz przeciwnie, analiza wymiany bezpośredniej jest użyteczna tylko jako wstęp do analizy społeczeństwa stosującego wymianę pośrednią. Wymiana bezpośrednia pozostawiałaby niewiele przestrzeni dla rynku lub produkcji. (Rothbard, 2007b, 334) 
Intencją autora była nie tylko krytyka klasycznej dychotomii, lecz także odrzucenie neutralności instytucjonalnej poprzez twierdzenie, że nie sam fakt istnienia pieniądza jest na tyle istotny i że powinno się analizować wartości nominalne jednocześnie z realnymi.

W kwestii jednostek pieniężnych Rothbard pisał następująco:

Jest jasne, że wielkość jednostki towaru pieniężnego wybrana do przeprowadzenia transakcji jest bez znaczenia dla analizy ekonomicznej i jest to kwestia wygody stron. Wszystkie jednostki będą jednostkami wagi i będzie je można przeliczyć na funty, uncje, itd., mnożąc lub dzieląc daną wielkość przez określoną liczbę. Jeden funt złota będzie się równał 16 uncjom i, oczywiście, zostanie wymieniony za 16 uncji, gdyby na rynku zaistniała potrzeba takiej transakcji. Brak ekonomicznego znaczenia nazw i rozmiarów jednostek można zobaczyć na następującym przykładzie. (Rothbard, 2007b, 338)

Z tego wynika, że nazwy nie są istotne. Opisana sytuacja jest analogiczna do sytuacji ze zmianą dolara na półdolara. Nie jest to jednak stanowisko w sprawie neutralności pieniądza. Rothbard zajmuje je, odnosząc się do form jednostek towaru:

Oczywiście im cenniejsze są jednostki jakiegoś towaru, tym mniejsza będzie wielkość jednostek stosowanych w codziennych transakcjach. Platyna będzie sprzedawana w uncjach, a żelazo w tonach. Transakcje przy użyciu relatywnie cennych towarów pieniężnych, takich jak złoto lub srebro, będą prowadzone z reguły w małych jednostkach wagowych. Ten fakt również nie ma istotnego znaczenia ekonomicznego. Forma jednostki towaru podyktowana jest kwestią użyteczności w danych okolicznościach. Żelazo może być sprzedawane w sztabach, ser w prostokątnych lub trójkątnych kawałkach itd. (Rothbard, 2007b, 339)

Podobnie jak nazwy forma jednostek pieniądza jest uznana za nieistotną. Forma świadczy o podzielności, a co za tym idzie, o ilości jednostek w obiegu. Uznam więcej, że neutralność statyczna jest w ramach ASE założeniem co najmniej dopuszczalnym.

Autor przytoczonych słów jest uważany za jednego z najważniejszych przedstawicieli swojego nurtu, wyznaczającego pewne standardy i poglądy przyjmowane w ramach szkoły austriackiej. Większość jego dorobku intelektualnego była podobna do dorobku Ludwiga von Misesa. W XX wieku jest jeszcze jedna osoba o tak dużym wpływie na austriacką teorię pieniądza — wspomniany już Friedrich von Hayek. Mimo pewnych różnic między nimi w podejściu do polityki czy teorii monopolu są zgodni co do neutralności. Hayek również uważał, że zmiany M wywołują efekt Cantillona, podkreślał przy tym brak doskonałej informacji. Zwracał uwagę na fakt, że pieniądz umożliwia oszczędzanie (Steele, 2011, 4) — z tego powodu nie uznawał on neutralności instytucjonalnej.

Bazując na poglądach Rothbarda, wnioskuję o następującym układzie poglądów na neutralność pieniądza szkoły austriackiej: 
Tabela 3. Neutralność pieniądza a szkoła austriacka

\begin{tabular}{l|l|l}
\hline \multicolumn{1}{c|}{ Neutralność } & \multicolumn{1}{|c}{ Stosunek } & \multicolumn{1}{c}{ Uzasadnienie } \\
\hline W momencie & Niejednorodny & \\
\hline Statyczna & Pozytywny & Nieistotność formy pieniądza \\
\hline Instytucjonalna & Negatywny & $\begin{array}{l}\text { Nieużyteczność analizy wymiany bezpośredniej do ana- } \\
\text { lizy społeczeństwa używającego pieniądza }\end{array}$ \\
\hline W okresie & Negatywny & $\begin{array}{l}\text { Skupienie się na relatywnych cenach, niedoskonała in- } \\
\text { formacja itp }\end{array}$ \\
\hline Dynamiczna & Negatywny & Jw. \\
\hline Superneutralność & Negatywny & Jw. \\
\hline Monetarna & Negatywny & Jw. \\
\hline
\end{tabular}

Źródło: opracowanie własne.

\section{Neutralność pieniądza a teoria realnego cyklu koniunkturalnego}

Powstanie teorii realnego cyklu koniunkturalnego (RBC) powszechnie datuje się na 1982 rok, gdy Finn E. Kydland i Edward C. Prescott opublikowali Time to Build and Aggregate Fluctuations, i jak inne szkoły ekonomiczne tamtego okresu powstała jako alternatywa dla keynesizmu. Jest to model bazujący na neoklasycznych modelach wzrostu. Obecnie jest uznawany za część głównego nurtu ekonomii oprócz między innymi szkoły neoklasycznej, monetaryzmu, teorii racjonalnych oczekiwań i części szkół bazujących na myśli Johna M. Keynesa.

Pod wieloma względami jest przeciwieństwem omówionej szkoły austriackiej. W odróżnieniu od niej metoda RBC jest matematyczno-empiryczna i czyni wiele uproszczeń w imię większej ilości predykcji. Pomija efekty zewnętrzne, działania rządu, asymetrię informacji i jakiekolwiek nieracjonalne oczekiwania (Kolasa, 2012, 114). W ramach niej zakłada się, że ceny są doskonale elastyczne.

Jeśli zjawiska monetarne wpływają na Y, to powinny być zmiennymi objaśniającymi funkcji produkcji. W RBC ma postać funkcji Cobba-Douglasa:

$$
\mathrm{Yt}=\mathrm{At} \mathrm{Kt}{ }^{\alpha}(\mathrm{XtNt})^{1-\alpha}
$$

gdzie:

$\mathrm{Yt}$ - produkt finalny

At - komponent losowy postępu technologicznego; w nim upatrywana jest przyczyna cyklów koniunkturalnych opisywanych przez RBC 
$\mathrm{Xt}$ — komponent deterministyczny postępu technologicznego; wyraża on wzrost w długim okresie, jest on liniowy

$\mathrm{Kt}$ - nakład kapitału

$\mathrm{Nt}$ - nakład pracy

$\alpha$ - parametr skalujący; w tym przypadku zakłada on stałe korzyści skali, ponieważ jest obecny w wykładniku obu elementów (gdy suma wykładników wynosi 1 , to zmiana obu podstaw potęg o $\mathrm{x} \%$ da zmianę Yt również o $\mathrm{x} \%$ )

RBC wykorzystuje także standardowy wzór:

$$
\mathrm{Yt}=\mathrm{Ct}+\mathrm{It}
$$

gdzie:

$\mathrm{Ct}$ - konsumpcja

It - inwestycje

Podane wzory są tylko kilkoma $\mathrm{z}$ wielu zawierających się w RBC. Nie uwzględniają one zjawisk monetarnych. Według zwolenników tej teorii cykle koniunkturalne są spowodowane szokami podażowymi wyrażanymi zmienną At, a więc trudnymi do przewidzenia zmianami technologicznymi. Pieniądz jest w tym modelu absolutnie neutralny. RBC łączy teorie wzrostu gospodarczego i fluktuacji, co oznacza odrzucenie rozróżnienia między długim i krótkim okresem (Chrupczalski, 2006, 93). Następstwem tego jest niemożliwość uznania neutralności w długim okresie i nieneutralności w krótkim, tak jak ma to miejsce w monetaryzmie. Takie założenia są bardzo istotne dla poglądów gospodarczych — implikują nieefektywność polityki monetarnej.

Nie można jednak uznać owej teorii za kompletną w takiej postaci. Pieniądz i produkcja są z sobą wyraźnie dodatnio skorelowane — ten fakt wymaga wyjaśnienia. W kwestii wzajemnych oddziaływań sfery monetarnej i sfery realnej są możliwe cztery ogólne podejścia:

- sfera monetarna oddziałuje na sferę realną, lecz nie odwrotnie,

- sfera realna oddziałuje na sferę monetarną, lecz nie odwrotnie,

- obie sfery na siebie wzajemnie oddziałują,

— obie sfery na siebie nie oddziałują.

Pierwszą i trzecią możliwość wyklucza postać funkcji produkcji RBC. Możliwość czwarta jest odrzucona ze względu na wspomnianą dodatnią korelację. Zostaje rozwiązanie drugie. Zwolennicy teorii realnego cyklu koniunkturalnego rozwiązują problem właśnie poprzez odwrócenie standardowego związku przyczynowo-skutkowego między zmianami monetarnymi a zmianami realnymi. $\mathrm{Uj}$ mując to inaczej można rzec, że te pierwsze są zdeterminowane, a te drugie są determinujące. Istota charakteru tych zmian jest zawarta w tym, że technologiczne szoki podażowe zwiększają popyt na usługi transakcyjne i depozyty bankowe (Sieroń, 2017, 64). 
Jasno pokazuje to stosunek teoretyków RBC do neutralności w okresie. Jednak o neutralności w momencie sam model się nie wypowiada, ponieważ ma charakter dynamiczny.

Można przypuszczać, że ekonomiści piszący w tradycji RBC będą zazwyczaj zakładać neutralność statyczną i neutralność instytucjonalną. Wynika to z ogólnego stwierdzenia, że sfera realna nie ma determinantów wśród zjawisk pieniężnych. Trzeba jednak pamiętać, że w przypadku tego nurtu jakość predykcji jest ważniejsza niż realistyczność założeń.

Podsumowując rozdział, wnioskuję, że układ poglądów na neutralność pieniądza w teorii realnego cyklu koniunkturalnego jest następujący:

Tabela 4. Neutralność pieniądza a teoria realnego cyklu koniunkturalnego

\begin{tabular}{l|l|l}
\hline \multicolumn{1}{c|}{ Neutralność } & \multicolumn{1}{|c}{ Stosunek } & \multicolumn{1}{c}{ Uzasadnienie } \\
\hline W momencie & $\mathrm{x}$ & $\mathrm{x}$ \\
\hline Statyczna & $\mathrm{x}$ & $\mathrm{x}$ \\
\hline Instytucjonalna & $\mathrm{x}$ & $\mathrm{x}$ \\
\hline W okresie & Pozytywny & Skupienie się na podażowej stronie gospodarki \\
\hline Dynamiczna & Pozytywny & Jw. \\
\hline Superneutralność & Pozytywny & Jw. \\
\hline Monetarna & Pozytywny & Jw. \\
\hline
\end{tabular}

Źródło: opracowanie własne.

\section{Neutralność pieniądza a keynesizm}

Keynesizm był szkołą dominującą w latach czterdziestych, pięćdziesiątych i sześćdziesiątych XX wieku. Zmienił on postrzeganie gospodarki w sposób radykalny i przekierował politykę gospodarczą w stronę umiarkowanego interwencjonizmu. $\mathrm{W}$ centrum tego nurtu znajduje się teoria zatrudnienia $\mathrm{z}$ takimi pojęciami, jak: skłonność do konsumpcji, skłonność do inwestycji, popyt efektywny, pełne zatrudnienie i mnożnik. Są one jednak przesączone czynnikami monetarnymi (takimi jak jednostka wartości pieniężnej). Owe czynniki są — podobnie jak wiele innych używanych w ramach danej szkoły — traktowane przez pryzmat krótkiego okresu i wielkości zagregowanych.

Trzema głównymi dziełami Johna M. Keynesa, uwzględniającymi teorię pieniądza, były Traktat o reformie pieniężnej, Traktat o pieniądzu i Ogólna teoria zatrudnienia, procentu i pieniadza. Ta ostatnia była kluczowa w rozwoju myśli ekonomicznej, a sposób, w jaki autor przedstawił w niej teorię ekonomii, wszedł do kanonu ekonomii. 
Przedmiotem keynesowskiej teorii pieniądza jest badanie zależności między zjawiskami monetarnymi a cenami (Rączkowski, 1948, 142). Ceny uzależnione są od stopy wynagrodzenia czynników produkcji wchodzących do kosztu krańcowego i od rozmiarów produkcji. Przy założeniu, że pierwszy czynnik zmienia się proporcjonalnie dla wszystkich czynników produkcji, możemy pozwolić sobie na uproszczone stwierdzenie, że P zależy od jednostki płac (płacy nominalnej za jednostkę pracy) i rozmiarów zatrudnienia. Zmiany M mogą wpływać na oba te elementy.

Keynes uważał, że związek zachodzi inaczej w stanie pełnego zatrudnienia niż w przypadku bezrobocia:

W tym wypadku, dopóki istnieje bezrobocie, mamy stałe przychody i sztywną jednostkę płac. Wynika stąd, że dopóki istnieje bezrobocie, wzrost ilości pieniądza nie wywiera żadnego wpływu na ceny, a zatrudnienie zwiększa się ściśle proporcjonalnie do każdego przyrostu efektywnego popytu wywołanego przez wzrost ilości pieniądza. Od chwili zaś kiedy zostanie osiągnięte pełne zatrudnienie, jednostka płac i ceny zaczną wzrastać ściśle proporcjonalnie do wzrostu efektywnego popytu. (Keynes, 2003, 268)

Oczywiście jest to obraz uproszczony na potrzeby wytłumaczenia głównej idei. W rzeczywistości popyt efektywny wcale nie zmienia się „ściśle proporcjonalnie" do wzrostu M, przychody mają malejący charakter (a nie stały), jednostka płacy ma tendencje do wzrostu przed osiągnięciem pełnego zatrudnienia. Te i kilka innych właściwości komplikują strukturę teorii pieniądza.

Po śmierci twórcy omawianego nurtu uznanie w nim zaczęła zdobywać krzywa Phillipsa ukazująca wymienność inflacji i bezrobocia.

Widać więc wyraźnie, że są to poglądy nie do pogodzenia z neutralnością w okresie. Nieneutralność pieniądza to warunek sprawiający, że inflacyjna polityka monetarna zalecana przez Keynesa może być skuteczna. Jest to opis krótkiego okresu. Długiemu okresowi nie poświęca się aż tyle uwagi.

Neutralność w momencie nie jest istotna dla tego nurtu. Można jednak stwierdzić, że w jego obrębie wielkość M nie ma znaczenia ze statycznego punktu widzenia — dlatego tak ważne jest rozróżnienie na płace nominalne i realne. Używanie pojęć pieniężnych jest istotne w analizach ekonomicznych:

Ale chociaż teoria równowagi zmiennej musi być rozwijana w ramach pojęć gospodarki pieniężnej, nie przestaje być ona w dalszym ciągu teorią wartości i podziału i nie staje się odrębną teorią pieniądza. Pieniądz, jeśli chodzi o jego najważniejsze własności, stanowi przede wszystkim subtelny środek wiązania teraźniejszości z przyszłością i bez wprowadzania pojęć pieniężnych nie możemy nawet zacząć rozważa jakie skutki ma zmiana przewidywań dla bieżącej działalności. (Keynes, 2003, 26)

W keynesizmie stosunek do neutralności pieniądza przedstawia się następująco: 
Tabela 5. Neutralność pieniądza a keynesizm

\begin{tabular}{l|l|l}
\hline \multicolumn{1}{c|}{ Neutralność } & \multicolumn{1}{c|}{ Stosunek } & \multicolumn{1}{c}{ Uzasadnienie } \\
\hline W momencie & Niejednorodny & \\
\hline Statyczna & Pozytywny & $\begin{array}{l}\text { Brak funkcji pieniądza wywołującej zmiany realne tyl- } \\
\text { ko ze względu na swoją ilość }\end{array}$ \\
\hline Instytucjonalna & Negatywny & $\begin{array}{l}\text { Istotność pieniądza w wiązaniu teraźniejszości z przy- } \\
\text { szłością }\end{array}$ \\
\hline W okresie & Negatywny & Wymienność inflacji i bezrobocia \\
\hline Dynamiczna & Negatywny & Jw. \\
\hline Superneutralność & Negatywny & Jw. \\
\hline Monetarna & Negatywny & Jw. \\
\hline
\end{tabular}

Źródło: opracowanie własne.

\section{Wnioski}

Celem tej pracy było rozwinięcie systematyki neutralności pieniądza zawartej w Efekcie Cantillona A. Sieronia oraz uporządkowanie przy jej pomocy założeń wybranych szkół ekonomicznych. Z każdego z nich wybrałem pracę lub kilka prac, które są dostatecznie reprezentatywne dla stosunku danego nurtu do teorii pieniądza.

Praca $\mathrm{z}$ pewnością nie wyczerpuje założonego tematu nawet $\mathrm{w}$ obrębie tylko czterech wybranych szkół, gdyż nie pokazuje wyjątków od regularności, jakimi są wymienione w tabelach założenia. W zakresie bardziej teoretycznym neutralności w ogóle nie zostały opisane (co wymagałoby odrębnego, dłuższego opracowania)

Pierwszy rozdział zawiera klasyfikację założeń o neutralności. Wartość dodana, jaką starałem się wnieść względem głównego źródła, na którym się opierałem, to: uwypuklenie podziału na okres i moment, zwrócenie większej uwagi na koszty transakcyjne w neutralności statycznej, ukazanie jej relacji z neutralnością instytucjonalną, dodanie do definicji neutralności dynamicznej słowa ,jednostajna” w celu oddzielenia jej bliźniaczego założenia oraz rozwinięcie superneutralności.

Pod koniec każdego rozdziału umieszczałem tabelaryczne podsumowanie, będące wnioskami z moich studiów literaturowych. Pokazały one poglądy szkół najbardziej wpływowych w obszarze nowoczesnej teorii pieniądza.

Reasumując, należy stwierdzić, że poglądy na neutralność pieniądza poszczególnych szkół pokazują konsensus między nimi co do neutralności w momencie. W głównym nurcie zakłada się neutralność dynamiczną w długim okresie, w przeciwieństwie do okresu krótkiego. „Superneutralność” i „neutralność monetarna" są pojęciami młodszymi i zazwyczaj nie uznaje się ich. 
Powoduje to powszechne przekonanie o istotnym wpływie polityki monetarnej. Fakt, że dotyczy to tylko krótkiego okresu, wymaga ciągłej działalności banku centralnego. Większość ekonomistów uważa, że w ten sposób można zwiększyć dobrobyt społeczeństwa.

\section{Bibliografia}

Chrupczalski, S. (2006), Cykle koniunkturalne a polityka monetarna na przykładzie Stanów Zjednoczonych. Kraków: publikacja samodzielna. Data dostępu: 6.01.2019, https://docplayer. pl/5057444-Cykle-koniunkturalne-a-polityka-monetarna-na-przykladzie-stanow-zjednoczonych.html.

Friedman, M. (1994). Intrygujący pieniądz. Łódź: Wydawnictwo Łódzkie.

Hume, D. (2014). O pieniądzu. Studia z historii filozofii, 1(5), 9-20.

Investopedia, thumaczenie własne. Data dostępu: 30.11.2018, https://www.investopedia.com/terms/n/ neutrality_of_money.asp.

Keynes, J. M. (2003). Ogólna teoria zatrudnienia, procentu i pieniądza. Warszawa: Wydawnictwo Naukowe PWN.

Kolasa, M. (2012). Teoria realnego cyklu koniunkturalnego. Studia i Prace Kolegium Zarzadzania i Finansów/Szkoła Główna Handlowa, 119, 91-121.

Menger, C. (2011). O naturze i pochodzeniu pieniądza. Data dostępu: 30.11.2018, https://mises.pl/ blog/2011/10/30/menger-o-naturze-i-pochodzeniu-pieniadza/.

Rączkowski, S. (1948). Teoria pieniądza J.M. Keynes 'a. Łódź: Wydawnictwo Kazimierza Rutskiego.

Rothbard, M. (2007a). Ekonomia wolnego rynku, t. I. Warszawa: Fijorr Publishing.

Rothbard, M. (2007b). Ekonomia wolnego rynku, t. II. Warszawa: Fijorr Publishing.

Samuelson, P., Nordhaus W. (2012). Ekonomia. Poznań: Dom Wydawniczy REBIS.

Steele, G. (21.02.2011). Hayekowska teoria pieniadza i cykli: retrospektywa i ponowna ocena. Data dostępu: 1.12.2018, https://mises.pl/blog/2011/02/21/steele-hayekowska-teoria-pieniadza-i-cykli-retrospektywa-i-ponowna-ocena/.

Sieroń, A. (2017). Efekt Cantillona - czyli dlaczego pieniadz ma znaczenie. Warszawa: CeDeWu. Skousen, M. (2015). Logika ekonomii. Warszawa: Fijorr Publishing.

Tradingeconomics. Data dostępu: 1.12.2018, https://pl.tradingeconomics.com/venezuela/inflation-cpi\#calendar-table.

Wikipedia, tłumaczenie własne. Data dostępu: 30.11.2018, https://en.wikipedia.org/wiki/Neutrality_of_money. 